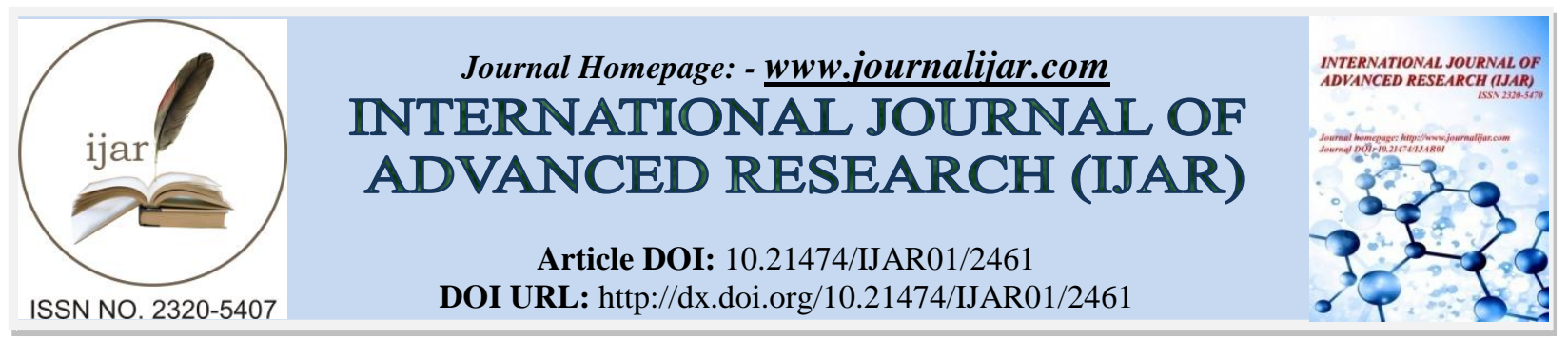

RESEARCH ARTICLE

\title{
SYNTHESIS AND EVALUATE OF SOME NEW 1,2,4-TRIAZOLES TO MODIFY EPOXY RESINS IN THE FIELD OF ANTI-MICROBIAL AND ANTI-CORROSIVE ORGANIC COATING.
}

\author{
N. Abd El-Khalik.
}

Assist. Professor, Department of Chemistry, Faculty of Science(Girls), Al-Azhar University, Cairo, Egypt.

\section{Manuscript Info}

Manuscript History

Received: 5 November 2016

Final Accepted: 17 December 2016

Published: January 2017

Key words:-

Epoxy resins, Anti-microbial coating, Anti-corrosive coating.

\section{Abstract}

Some recent amino triazole derivatives mainly 4-amino-5(trifluoromethyl)-4H-1,2,4-triazole-3-thiol (I) , 4-((4chlorobenzylidene)amino)-5-(trifluoromethyl)-4H-1,2,4-triazole-3-

thiol (II), 4-((furan-2-ylmethylene)amino)-5-(trifluoromethyl)-4H1,2,4-triazole-3-thiol (III) and Ni [ II ] complex (IV ) were synthesized and their chemical structures were confirmed by spectral data . The synthesized amino triazole compounds (I-IV) were physically incorporated into epoxy coating formula by the ratio of 0.5 , $1.0,2.0$ and $3.0 \%$ by weight, in order to achieve a proper ratio of amino triazole derivatives to produce a green epoxy formulation for surface coating application. The modified epoxy varnishes were evaluated as anti-corrosion performance of mild steel coated specimens by employing salt spray test, also their antimicrobial activity against six different microbial strains mainly are Grampositive bacteria: Staphylococcus aureus (ATCC25923) and Bacillus subtilis (ATCC6635), Gram - negative bacteria: Escherichia coli (ATCC 25922) and Salmonella typhimurium (ATCC 14028) and Yeast: Candida albicans (ATCC 10231) and Fungus: Aspergillus fumigates were screened.

Copy Right, IJAR, 2016,. All rights reserved.

\section{Introduction:-}

The industrial use of thermoset polymers is rapidly growing worldwide due to their high performance capabilities in demanding environments. Epoxy resins are one of the most versatile thermoset polymers and are prevalent because of their ability to polymerize or "cure" under a wide range of conditions. Epoxy resins also offer a good to excellent mechanical properties, good electrical insulating properties and excellent adhesion to a wide variety of substrates, so it has a prevalently uses in a wide range of applications. Additionally, once cured, epoxy resins exhibit excellent chemical resistance as anticorrosive metal coatings ${ }^{(1-3)}$. It is generally believed that most organic coatings adhere to metals via hydrogen bonds or secondary bonds, therefore, these bonds develop when an organic coating and a metallic surface are brought closely together and so the binders with polar groups display excellent adhesion characteristics. The bond strength of epoxy resins on steel is strongly dependent on the hydroxyl group content. It was found that the epoxy compounds were dissociated between the phenoxy oxygen and the aliphatic carbon. The surface interactions were believed to be via the phenoxy and hydroxyl oxygen atoms ${ }^{(4)}$, as illustrated in Fig (1).

Corresponding Author:- N. Abd El-Khalik.

Address:- Assist. Professor, Department of Chemistry, Faculty of Science (Girls), Al-Azhar University, Cairo, Egypt. 


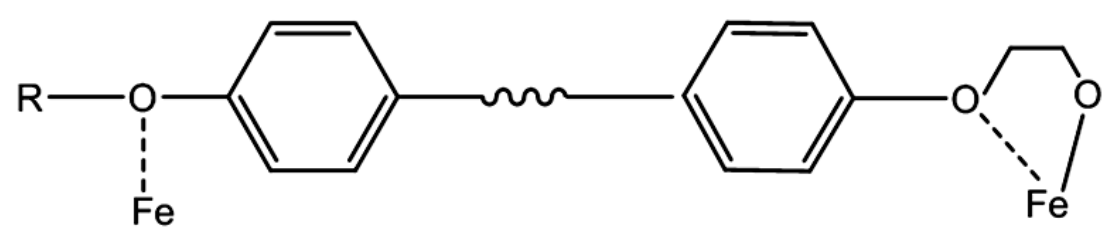

Figure 1: Adhesion of epoxy to steel by interacfacial bonds

The three main applications for epoxy resins are coatings, composites, and structural adhesives ${ }^{(5)}$.

Antimicrobial coatings are useful in the development of hygienic surfaces. These are having some antimicrobial agent in their composition that either can kill or inhibit the growth of microorganisms ${ }^{(6)}$. These types of coatings have immense applications in the design of materials and devices in health care sector, hospital surfaces, surgery equipment, health-care products and water purification systems ${ }^{(7)}$.Commonly used antimicrobial surfaces contain some antibiotics, silver ions, quaternary ammonium cations, halogens or some heterocyclic compounds ${ }^{(8)}$.

Triazolic nucleus is nowadays considered an important moiety in the design and synthesis of bioactive compounds that are associated with numerous biological activities such as antibacterial and antifungal ${ }^{(9-12)}$. Also, there are some reviews indicate that 1,2,4-triazoles occupy a distinctive place in the field of medicinal and pharmaceutical chemistry ${ }^{(13,14)}$, as well as in industry ${ }^{(15)}$. Recently some triazole derivatives were added to polyurethane coating which demonstrate an impressive results as antimicrobial ${ }^{(16)}$.

Annual costs related to corrosion and corrosion prevention constitutes a substantial part of the gross national product in the world. Although the value of these numbers is always debatable, but the corrosion has great importance in modern societies in addition to economic costs and technological delay, corrosion can lead to failure of metal structures which have serious consequences for humans and the environment ${ }^{(17,18)}$. Thus, the study of mild steel corrosion and the inhibition of mild steel corrosion have invited the attention of scientists and technocrats to devise ways to control the corrosion. Between the various corrosion control modes, the use of corrosion inhibitors is a familiar method. Inhibition efficiency always depends upon the number of active adsorption centers of inhibitor molecule may have, and the charge density, molecular size, mode of adsorption, and its capability to form metallic complexes ${ }^{(19-21)}$.

Over the last decades, both organic and inorganic coatings have been widely applied for the protection of metals against corrosion. In many areas of coatings technology, anticorrosive paint gave great attention. Most of the efficient inhibitors used in industry are organic compounds that mainly contain a nitrogen atom, a sulfur atom and multiple bonds in the molecules through which they are adsorbed onto the metal surface. Even though a large number of organic compounds are available, the choice of an appropriate inhibitor for a particular system is very limited, due to the specificity of the inhibitors and the great variety of corrosion-related applications ${ }^{(22,23)}$. A survey of the available literature reveals that (amongst others) the inhibitive effects of alcohols, amides, amines, anilines, azoles ${ }^{(24)}$, mercaptans, oximes, thioethers, and dithiobiurets ${ }^{(25)}$ have been studied.

Triazole-type organic compounds are good corrosion inhibitors for many metals and alloys in various aggressive media ${ }^{(26-29)}$.

In the present work, a study has been conducted on the effect of 1,2,4-triazoles such as 4-amino-5- (trifluoromethyl)4H-1,2,4-triazole-3-thiol (I) , 4-((4-chlorobenzylidene)amino)-5-(trifluoromethyl)-4H-1,2,4-triazole-3-thiol (II), 4((furan-2-ylmethylene) amino)-5-(trifluoromethyl)-4H-1,2,4-triazole-3-thiol (III) and Ni [II] complex (IV) on biological activity and anti-corrosion performances of epoxy resin varnish.

\section{Experimental:-}

Materials:-

Epoxy resin was obtained from Pachin Pints Company - Egypt, all other chemicals used are pure grade quality get from Sigma- Aldrich Chemical Co. All the melting points were determined by open capillary method and are uncorrected. Chemical structure of the prepared triazole derivatives were confirmed using, a Perkin-Elmer 240 micro-analyzer at the Micro-Analytical Center of Cairo University, IR spectra were determined as (KBr) pellets on a 
Jasco FT/IR 460 plus spectrophotometer at Faculty of Science, Al-Azhar university. ${ }^{1} \mathrm{H}$ NMR spectra were recorded using a BRUKER AV $300 \mathrm{MHz}$ spectrometer using in $\mathrm{CDCl}_{3}$ or DMSO as an internal standard, MS were measured on a Shimadzu GC/MS-QP5 spectrometer at Faculty of Science, Cairo University and (TGA and DTA) were carried out using TGA-50H and DTA-50H at Ain Shams University Faculty of Science Central Lab.

Methods and techniques Synthesis of 1,2,4-triazole derivatives:-

New anti-microbial additives based on 1,2,4-triazole derivatives (I-IV) were prepared as represented in Scheme (1).

Synthesis of 4-amino-5- (trifluoromethyl)-4H-1,2,4-triazole-3-thiol ( I ) ${ }^{(30)}$.

An equimolar mixture of thiocarbohydrazide ( $10 \mathrm{mmol}$ ) and trifluoroacetic acid ( $10 \mathrm{mmol})$ was warmed carefully between $160-170{ }^{\circ} \mathrm{C}$ until melting occurred, heating lasts for 15 minutes after melting . The reaction mixture was cooled and mixed with $80 \mathrm{ml}$ of water. The precipitate was filtered, washed with water and oven dried. A colorless crystals; m.p:140 - $141^{0} \mathrm{C}$; yield $85 \%$; IR $(\mathrm{KBr}) \mathrm{cm}^{-1}: 3314,3200\left(\mathrm{NH}_{2}\right), 2572(\mathrm{~S}-\mathrm{H}), 1630 \quad(\mathrm{C}-\mathrm{S}), 1460(\mathrm{C}=\mathrm{N}$ in triazole), 1242,1147 (C-N),1082,1005(C-F); ${ }^{1} \mathrm{H}$ NMR (in $\left.\mathrm{CDCl}_{3}\right)(\delta \mathrm{ppm}): 11.64(\mathrm{~s}, 1 \mathrm{H}, \mathrm{SH}), 4.83(\mathrm{~s}, 2 \mathrm{H}, \mathrm{NH}) ; 19 \mathrm{~F}$ $\operatorname{NMR}(\delta \mathrm{ppm}) 66.24$ (s, 3F, $\left.\mathrm{ArCF}_{3}\right) ; \mathrm{MS}: \mathrm{m} / \mathrm{z}(\%): 184\left[\mathrm{M}^{+}\right](100), 126(11), 111(5), 96(8), 85(1), 78(12), 69(30)$, 60(23), 57(13), 45(8); Anal. Calcd. for $\mathrm{C}_{3} \mathrm{H}_{3} \mathrm{~N}_{4} \mathrm{~S} \mathrm{~F}_{3}$ : C, 19.57; H, 1.64; N, 30.43\% Found: C, 19.45; H, 1.59; N, $30.06 \%$.

Synthesis of 4-((4-chlorobenzylidene)amino)-5-(trifluoromethyl)-4H-1,2,4-triazole-3-thiol ( II ):In $50 \mathrm{ml}$ round bottom flask a mixture of compound (I) $(10 \mathrm{mmol}),(10 \mathrm{mmol})$ of p-chlorobenzaldehyde and $(0.5 \mathrm{~mL})$ of acetic acid in $30 \mathrm{~mL}$ of ethanol was refluxed for $5 \mathrm{~h}$., filtrated on hot, cooling , the precipitate was filtered and washed with methanol. A pale yellow crystal from ethanol; m.p. $125-126^{0} \mathrm{C}$; yield $82 \% ; \mathrm{IR}(\mathrm{KBr}) \mathrm{cm}^{-1}$ : 3117 (Ar.H), 2539 (SH), 1508 (C=C), 1630 (C=N Schiff base), 1568 (C=N in triazole), 1298 (C-N in triazole) , $1016\left(\mathrm{~N}-\mathrm{N}\right.$ in triazole); ${ }^{1} \mathrm{NMR}(\delta \mathrm{ppm})$ ( in DMSO): $11.04(\mathrm{~s}, 1 \mathrm{H}-\mathrm{SH}), 8.63(\mathrm{~s}, 1 \mathrm{H}-\mathrm{CH}), 7.00-7.85(\mathrm{~m}, 4 \mathrm{H}-\mathrm{Ar}-\mathrm{H})$ ;Anal. Calcd.for $\mathrm{C}_{10} \mathrm{H}_{6} \mathrm{~N}_{4} \mathrm{~S} \mathrm{~F} \mathrm{~F}_{3} \mathrm{Cl}$ : C, 39.15; H, 1.96; N, 18.27\% - Found: C, 39.76; H, 2.13; N, 17.83\%

Synthesis of 4-((furan-2-ylmethylene)amino)-5-(trifluoromethyl)-4H-1,2,4-triazole-3-thiol ( III ):-

In $50 \mathrm{ml}$ round bottom flask a mixture of compound ( I ) ( $10 \mathrm{mmol})$, ( $10 \mathrm{mmol}$ ) of furan-2-carbaldehyde and $(0.5 \mathrm{~mL})$ of acetic acid in $30 \mathrm{~mL}$ of ethanol was refluxed for $5 \mathrm{~h}$., filtrated on hot, cooling, the precipitate was filtered and washed with methanol. A reddish - brown crystals from $N, N$-Dimethylformamide; m.p. $147-148^{0} \mathrm{C}$; yield 91\%; IR (KBr) $\mathrm{cm}^{-1}$ : $2529(\mathrm{SH}), 1613$ ( C=N Schiff base), 1551(C=N in triazole), $1480(\mathrm{C}=\mathrm{C}), 1290(\mathrm{C}-\mathrm{N}$ in triazole) , $1018(\mathrm{~N}-\mathrm{N}) ;{ }^{1} \mathrm{NMR}(\delta \mathrm{ppm})(\mathrm{in} \mathrm{DMSO}): 10.12(\mathrm{~s}, 1 \mathrm{H}-\mathrm{SH}), 8.09(\mathrm{~s}, 1 \mathrm{H}-\mathrm{CH}), 6.75-7.61(\mathrm{~m}, 3 \mathrm{H}-\mathrm{Ar}-\mathrm{H})$; MS: m/z (\%):262[M+] (5.64),184.04 (59.46), 78.09 (23.64), 69.10 (100), 67.13 (23.55); Anal. Calcd. for $\mathrm{C}_{8} \mathrm{H}_{5} \mathrm{~N}_{4} \mathrm{~S}$ $\mathrm{O} \mathrm{F}_{3}: \mathrm{C}, 36.64 ; \mathrm{H}, 1.91 ; \mathrm{N}, 21.37 \%$ Found: C, 36.76; H, 2.13; N, $21.52 \%$.

\section{Synthesis of Nickel [II] Complex ( IV ):-}

A solution of nickel chloride $(10 \mathrm{mmol})$ in absolute warmed ethanol $(5 \mathrm{~mL})$ was slowly added drop wise to a solution of compound (I) $(10 \mathrm{mmol})$ in absolute ethanol $(10 \mathrm{~mL})$. The mixture was stirred for $30 \mathrm{~min}$. at room temperature and refluxed for $2 \mathrm{~h}$. The complex was filtered in a vacuum system, washed with ethanol several times and dried. A pure pale green solid was obtained; m. p. > $300{ }^{0} \mathrm{C}$; yield $62 \%$;

\section{Preparation of epoxy paint films containing 1,2,4- triazole derivatives ( I - IV ):-}

The epoxy paint compositions were prepared by physically incorporate 1,2,4- triazole derivatives, in the ratio of $0.5 \%, 1.0 \%, 2.0 \%$ and $3.0 \%$ by weight into epoxy paint. The samples of different molar ratio were then applied to both steel and glass by means of a brush. All efforts were made to maintain a uniform film thickness of $50 \pm 5 \mu$ m. for evaluating the physical and mechanical properties of the paint. The solid content was adjusted at $60 \%$.

\section{Physical and mechanical testing of coating films:-}

A range of physical and mechanical evaluations of the painted films were conducted according to appropriate American Society for Testing and Materials (ASTM) standard test methods. The color of epoxy resin formulations was measured using the Gardner standard color scale (ASTM D1544). The prepared steel panels (ASTM D 609-95) were used for measuring, the measure of film coating thickness (ASTM D 1005-07), the adhesion 'cross hatch' test (ASTM D 3359-02) and the flexibility 'bend' test (ASTM D 522-93a). Glass plates (100 mm- 150 mm), coated with the individual formulations, were utilized to measure the degree of gloss at an angle of 60॰ (ASTM D 523-08), and also to measure the film hardness by means of the pencil test (ASTM D 3363-00). 


\section{Antimicrobial screening:-}

The anti-microbial activity of the synthesized triazole derivatives ( I - IV ) was tested against six different microorganisms such as; Gram- positive bacteria: Staphylococcus aureus (ATCC 25923) and Bacillus subtilis (ATCC 6635), Gram - negative bacteria: Escherichia coli (ATCC 25922) and Salmonella typhimurium (ATCC 14028), Fungus: Aspergillus fumigates and Yeast: Candida albicans (ATCC 10231) in nutrient broth medium.

Paper disk diffusion method for the determination of antimicrobial activity ${ }^{(31)}$ :Paper disk diffusion is the official method used in many clinical microbiology laboratories to determine what antibiotics and compounds inhibit bacterial growth, or are bacteriostatic. The paper disks are soaked with a select antibiotic or chemical and then placed on a lawn of bacteria in a petri dish. The zones of inhibition are measured around where the disk was placed to determine whether the bacterium was resistant or susceptible to the particular antibiotic or chemical chosen. The sterilized (autoclaved at $120^{\circ} \mathrm{C}$ for $30 \mathrm{~min}$ ) medium at $\left(40-50{ }^{\circ} \mathrm{C}\right.$ ) was incubated $\left(1 \mathrm{ml} / 100 \mathrm{ml}\right.$ of medium) with the suspension $\left(105 \mathrm{cfu} \mathrm{ml}^{-1}\right)$ of the micro-organism (matched to McFarland barium sulfate standard) and poured into a petri dish to give a depth of 3-4 mm. The paper impregnated with the test compounds $\left(\mathrm{mg} / \mathrm{ml}^{-1}\right)$ was placed on the solidified medium. The plates were pre-incubated for $1 \mathrm{~h}$ at room temperature and incubated at $37{ }^{\circ} \mathrm{C}$ for 24 and $48 \mathrm{~h}$ for anti-bacterial and anti-fungal activities, respectively. Chloramphencol, Cephalothinin and cycloheximide (mg/disk) was used as a standard for Gram - positive, Gram negative and anti-fungal activities respectively.

\section{Anti-corrosive performance evaluation of formulations through salt spray Accelerated Testing:-}

The test pieces of mild steel were $20 \times 20 \times 2 \mathrm{~mm}$. The samples were first mechanically polished with a fine grade emery paper in order to obtain a smooth surface, followed by degreasing with acetone and then rinsed with distilled water, dried between two filter papers. A salt fog chamber was utilized for each of the resin formulations; with a set of three coated panels being placed in the salt spray chamber according to ASTM B117-03. The corrosion resistance was evaluated in terms of blistering, scribe failure and degree of rusting, in relation to ASTM standards, i.e. ASTM D714-02, D1654- 00 and D610-01 respectively.

\section{Results and Discussion:-}

In recent times triazole rich molecules have gained much importance in the field of polymer and material science so it is used prevalent in a wide range of applications because of their excellent properties like strong anti-microbial and anti fouling nature of the triazole ring along with easy synthetic procedures and exceptionally high yield of end product.

\section{Synthesis and characterization of triazole derivatives and nickel [ II ]complex:-}

In the present study, 1,2,4-triazole derivatives were successfully synthesized aiming to explore their antimicrobial and anticorrosion properties. The synthesis of triazole derivatives ( 1-IV ) was performed according to indications mentioned in experimental section and shown in scheme ( 1 ). The compounds were obtained with yields (62-91\%) with high purity, the products confirmed by TLC analysis and evaluation of melting point. The formation of 1,2,4triazole derivatives was proven by elemental analysis, FTIR and $\mathrm{H}^{1} \mathrm{NMR}$, as well as by mass spectrometry for the compounds.

\section{Characterization of nickel [ II ] complex (IV):-}

Comparison of IR spectrum of the free ligand with IR spectrum of the nickel [ II ] complex gives an idea about the changes that might occur during complex formation. The IR spectrum of the complex displayed the ligand characteristic bands with appropriate shifts due to complex formation and there are three features in the IR spectrum of the nickel [ II ] complex. The first feature is the shift of the stretching frequencies of the amino group $v\left(\mathrm{NH}_{2}\right)$ in the nickel [ II ] complex to lower frequencies compared with the free ligand band in the region $3309-3236 \mathrm{~cm}^{-1}$, indicating the formation of coordinate bond between nitrogen of amino group and nickel ion. This is consistence with the presence of a new weak band at $410 \mathrm{~cm}^{-1}$ assignable to $v(\mathrm{M}-\mathrm{N})$ vibration confirming the participation of amino group in coordination as was expected ${ }^{(32)}$.The second feature is that deprotonation of the thiol group as indicated by the absence of a characteristic band in the complex of $v(\mathrm{~S}-\mathrm{H})$ of ligand, indicating the formation of new bond between metal and sulfur. This is supported by the appearance a peak at $659 \mathrm{~cm}^{-1}$ in the metal complexes due to $v(\mathrm{C}-\mathrm{S})^{(33)}$. The third feature is that the appearance of broad band at $3401 \mathrm{~cm}^{-1}$ which can be assigned to the stretching frequencies of $v(\mathrm{OH})$ of water molecules either in the coordinated or uncoordinated form associated to the complexes which are also confirmed by thermal analyses as well as appearance of the non-ligand band at $554 \mathrm{~cm}^{-1}$ assignable to $v(\mathrm{M}-\mathrm{O})^{(34,35)}$. 
<smiles>NNC(=S)NNCC1C(C(F)(F)F)C1(F)F</smiles>

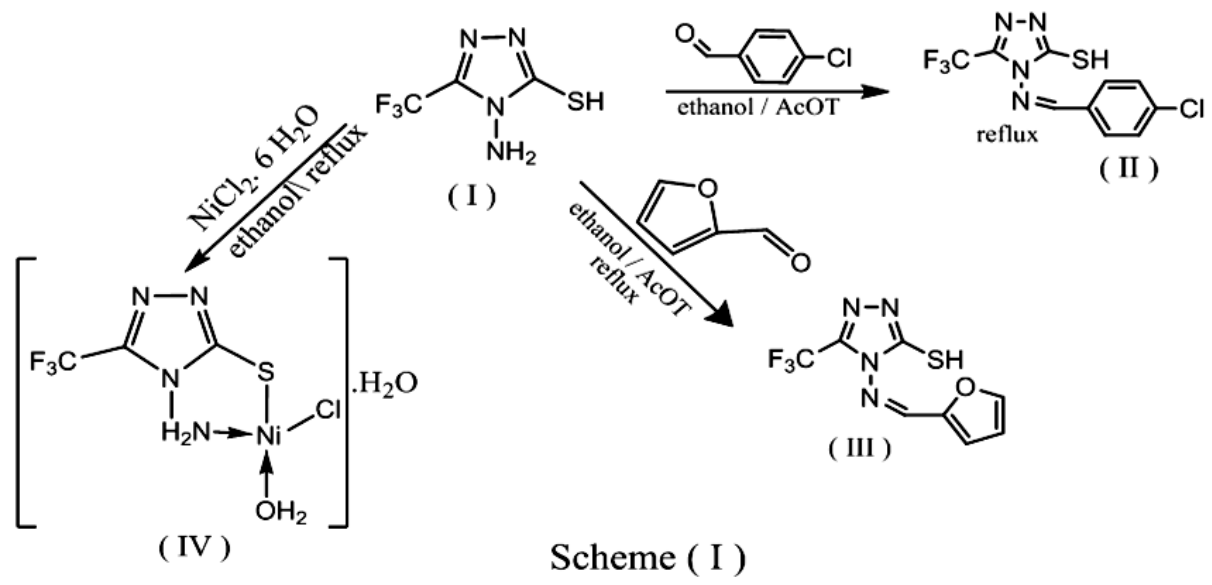

The measured effective magnetic moment value (3.36B.M) suggesting the magnetic behavior of the complex, in addition this value was consistent with the two unpaired electrons in tetrahedral geometry ${ }^{(36)}$. Mass spectrometry technique has been carried out to assisting the structural identification of the synthesized nickel [II] complex. The spectrum of this complex showed three important peaks. The first one shows the molecular ion peak with the highest value $\mathrm{m} / \mathrm{z}(\%)$ at $313.37(2.29)$ (Calcd. $313.33 \mathrm{amu}$ ), which agree well with the suggested formula weight and indicate the monomeric nature of the complex. The second peak observed at $\mathrm{m} / \mathrm{z}(\%)=97.14(33.23)$ ( Calcd. 96.69 amu) due to degradation of complex into $\mathrm{NiF}_{2}$ which decompose to $\mathrm{Ni}^{2+}$ giving the third peak at $\mathrm{m} / \mathrm{z}(\%)=57.12$ (100.00) (Calcd. $58.69 \mathrm{amu})$.

Moreover, thermal studies of complex was carried out to complete the characterization process; to get information about the thermal stability of the complex; to suggest a general scheme for thermal decomposition and to ascertain the nature of associated water molecules as well as to determine the final product of decomposition ${ }^{(37)}$. The TG DTG curve of complex presented in Fig. ( 2 ) and shows three steps of decomposition up to $500^{\circ} \mathrm{C}$. The first one at $40-42{ }^{\circ} \mathrm{C}$ with mass loss of $10.89 \%$ ( Calc. $11.50 \%$ ) due to the liberation of one hydrated and one coordinated water molecules. The second step with a weight loss of $25.17 \%$ ( Calc. $24.90 \%$ ) between $371-387^{\circ} \mathrm{C}$ was attributed to the liberation of by $1 / 2 \mathrm{~N}_{2}, \mathrm{~F}_{2}$ and $\mathrm{CN}$. The last step of decomposition corresponded to the liberation of $\mathrm{N}_{2}, \mathrm{HF}, \mathrm{HCl}$ and CS with a weight loss of $41.13 \%$ ( Calc. $41.03 \%$ ) between $457-501^{\circ} \mathrm{C}$. The overall mass loss is observed to be 77.19 $\%$ ( Calc. $77.43 \%$ ) leaving $\mathrm{Ni}$ and $\mathrm{C}$ as residue \{calculated: $22.57 \%$, found: $22.81 \%$ \}. Hence, the suggested structure of the complex with the molecular formula $\left[\mathrm{NiC}_{3} \mathrm{H}_{2} \mathrm{~N}_{4} \mathrm{SF}_{3}(\mathrm{Cl})\left(\mathrm{H}_{2} \mathrm{O}\right)\right] \cdot \mathrm{H}_{2} \mathrm{O}$ was given in scheme[1]. 


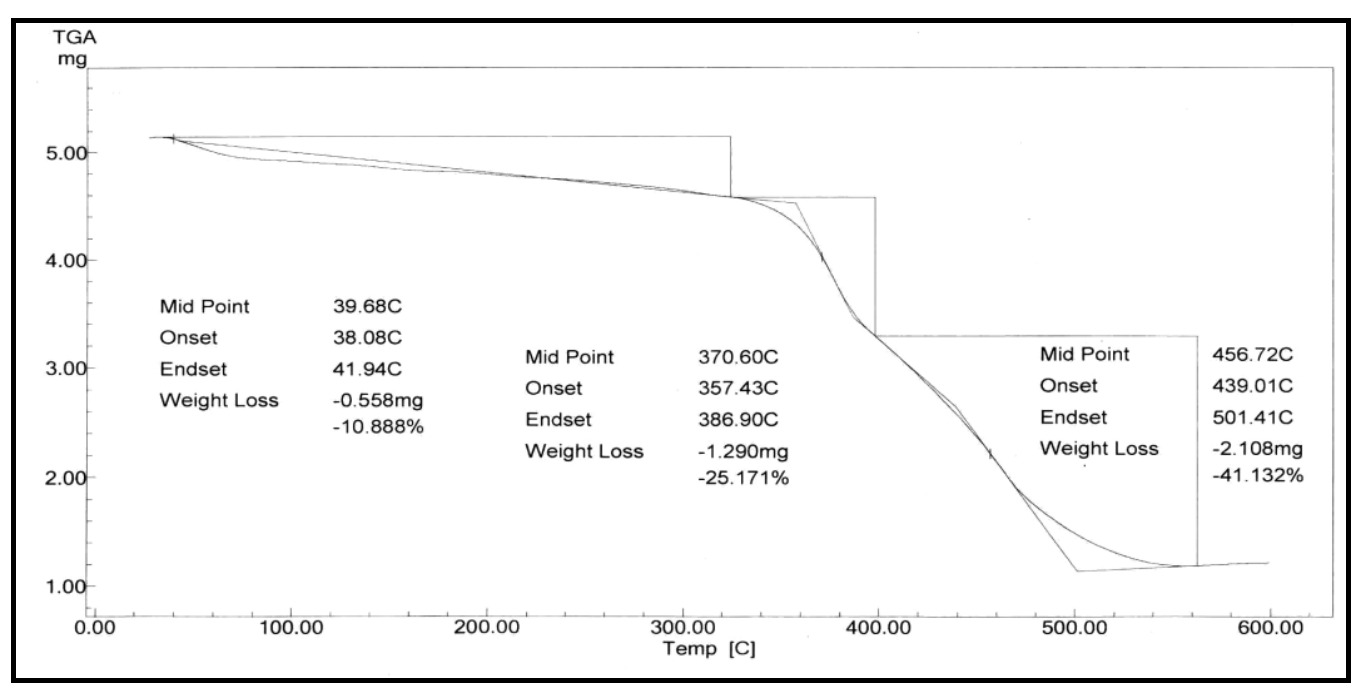

Figure 2 :- TG - DTG Spectrum of Nickel [II] Complex.

\section{Physical and mechanical testing of modified coating films:-}

Modified epoxy resins were evaluated for some physical and mechanical properties; also their antimicrobial and anticorrosive properties were examined. The effects of adding modifiers triazole derivatives to epoxy resin formulation, were evaluated using a variety of standard test methods. This was done to ascertain any positive or negative aspects that might arise due to the presence of the additives. The color, gloss, hardness, adhesion, flexibility and impact were measured. The resulting data is shown in Table (1).

All films of epoxy paint compositions gave a very clear, transparent and homogeneous appearance and showed an excellent hardness.

\section{Color:-}

Color was measured using the Gardner standard colors, which consists of 18 colors numbered from (1 to 18). The method determines the color by comparison with standards of definite color compositions. It could be seen that addition of compounds ( I ) increased the color level slightly in high percent, while addition of compound ( II ) increased the color levels by increasing the percent. This is obviously a negative result which may be attributed to the introduction of sulfur and nitrogenous base into epoxy coating formulations. Epoxy coating which developer by compound (III) acquired dark color due to the presence of furan ring beside sulfur and nitrogen, also addition of complex (IV) produces a dark paint color.

\section{Adhesion cross hatch test:-}

This test is in conformity according to (ASTM D 3359-02) where adhesion is assessed on a 0 to 5 scale. When study the hardness property of the neat epoxy and modified epoxy coating films, it was observed that the physically addition of the modifiers (I, II and III) increase hardens of coated films, and increasing the modifier percentage increases hardens value, while complex (IV) has slightly negative effects.

\section{Flexibility (bend) test:-}

The test was performed to determine the adhesion power of the coating to the substrate by bending apparatus. It is clear from the obtained results that the adding of new triazole derivatives didn't affect on the flexibility of the coating film, it can be stated that all the films showed a good flexibility. There was no significant difference between a blank epoxy coating film and modified epoxy coating films.

\section{Gloss:-}

This was measured using a Sheen UK gloss meter, it could be seen that the triazole additives (I, II and III) actually increased the gloss level. This result is attributed to the introduction of aromatic rings and a lone pair of electrons 
into the varnish formulations. And vice versa when adding compound ( IV ) the gloss level decreases, this may be due to the presence of nickel complex.

Table 1 :- Physical and mechanical characteristics of modified epoxy varnish with new triazole derivatives (compounds I- IV).

\begin{tabular}{|c|c|c|c|c|c|}
\hline Sample & Color & Adhesion & Flexibility & Gloss at $60^{\circ}$ & hardness \\
\hline Blank epoxy resin & 4 & 4 & Pass & 83 & Excellent \\
\hline Epoxy with comp. I $\quad 0.5 \%$ & 4 & 4 & Pass & 87 & Excellent \\
\hline $1.0 \%$ & 4 & 4 & Pass & 85 & Excellent \\
\hline $2.0 \%$ & 5 & 5 & Pass & 90 & Excellent \\
\hline $3.0 \%$ & 5 & 5 & Pass & 95 & Excellent \\
\hline Epoxy with comp. II $\quad 0.5 \%$ & 4 & 4 & Pass & 88 & Excellent \\
\hline $1.0 \%$ & 5 & 5 & Pass & 88 & Excellent \\
\hline $2.0 \%$ & $<6$ & 5 & Pass & 90 & Excellent \\
\hline $3.0 \%$ & 7 & 5 & Pass & 94 & Excellent \\
\hline Epoxy with comp. III $0.5 \%$ & $>18$ & 4 & Pass & 89 & Excellent \\
\hline $1.0 \%$ & $>18$ & 4 & Pass & 90 & Excellent \\
\hline $2.0 \%$ & $>18$ & 5 & Pass & 90 & Excellent \\
\hline $3.0 \%$ & $>18$ & 5 & Pass & 96 & Excellent \\
\hline Epoxy with comp. IV $0.5 \%$ & 14 & 4 & Pass & 80 & Excellent \\
\hline $1.0 \%$ & 16 & 3 & Pass & 81 & Excellent \\
\hline $2.0 \%$ & $>18$ & 3 & Pass & 76 & Excellent \\
\hline $3.0 \%$ & $>18$ & 3 & Pass & 73 & Excellent \\
\hline
\end{tabular}

Evaluation of triazole derivatives as antimicrobial and antifungal additives to epoxy paint:-

Biocide additives are commonly used to prolong the life of surface coatings. They prevent, or slow down, the growth of organism son the coating surface. Without biocide additives, the biological species start to adhere to the coating surface and this can eventually lead to disbonding and blistering of coatings, under various conditions.

Some of 1,2,4-triazole derivatives have been reported as antibacterial and antifungal ${ }^{(38,39)}$. In the present study some novel triazole derivatives expected to have a biocide activity were prepared and physically incorporate by the ratios of $[0.5 \%, 1.0 \%, 2.0 \%$ and $3.0 \%]$ as biocide against six different micro-organisms such as Gram- positive bacteria (Staphylococcus aureus, Bacillus subtili);Gram-negative bacteria (Escherichia coli, Salmonella typhimurium) ; Yeast (Candida albicans) and Fungus (Aspergillus fumigates). From the data give in the table (2) it is clear that epoxy varnish (blank) hasn't any antibacterial or antifungal activities, epoxy varnishes modified with compound (I) have high sensitivity to Gram - positive bacteria and Yeast and intermediate effect towards Fungi, epoxy varnishes modified with compound (II) may be used as antibacterial and antifungal for all six micro-organisms, while compound (III) the introducing of furan ring to 5-(trifluoromethyl) -1,2,4-triazole-3-thiol lead to reduce biocidal activity. Disappearance of free amino and thiol groups in complex (IV) lead to a lack of bacterial activity, but have a high resistance to fungi and yeast. 
Table 2:- Antibacterial and antifungal activities of modified epoxy varnish with new triazole derivatives (compounds I- IV).

\begin{tabular}{|c|c|c|c|c|c|c|}
\hline \multirow{2}{*}{$\begin{array}{l}\text { Organism } \\
\text { Sample }\end{array}$} & \multicolumn{2}{|c|}{ Gram - positive bacteria } & \multicolumn{2}{|c|}{ Gram - negative bacteria } & \multicolumn{2}{|c|}{ Yeasts and Fungi } \\
\hline & $\begin{array}{l}\text { Staphylococcus } \\
\text { aureus }\end{array}$ & $\begin{array}{l}\text { Bacillus } \\
\text { subtilis }\end{array}$ & $\begin{array}{l}\text { Salmonella } \\
\text { typhimurium }\end{array}$ & $\begin{array}{l}\text { Escherichia } \\
\text { coli }\end{array}$ & $\begin{array}{l}\text { Candida } \\
\text { albicans }\end{array}$ & $\begin{array}{l}\text { Aspergillusfu } \\
\text { migates }\end{array}$ \\
\hline Blank & - & - & - & - & - & - \\
\hline $\begin{array}{llll}\text { Epoxy } & \text { with } & \text { comp. } & \text { I } \\
0.5 \% & & & \end{array}$ & $14 \mathrm{I}$ & $23 \mathrm{H}$ & - & - & $30 \mathrm{H}$ & $8 \mathrm{~L}$ \\
\hline $1.0 \%$ & $20 \mathrm{I}$ & $24 \mathrm{H}$ & - & - & $30 \mathrm{H}$ & $11 \mathrm{~L}$ \\
\hline $2.0 \%$ & $27 \mathrm{H}$ & $30 \mathrm{H}$ & - & - & $30 \mathrm{H}$ & $14 \mathrm{I}$ \\
\hline $3.0 \%$ & $29 \mathrm{H}$ & $32 \mathrm{H}$ & - & - & $32 \mathrm{H}$ & $16 \mathrm{I}$ \\
\hline $\begin{array}{llll}\text { Epoxy } & \text { with } & \text { comp. } & \text { II } \\
0.5 \% & & & \end{array}$ & $12 \mathrm{I}$ & $15 \mathrm{I}$ & - & - & - & $9 \mathrm{~L}$ \\
\hline $1.0 \%$ & $20 \mathrm{I}$ & $18 \mathrm{I}$ & $14 \mathrm{I}$ & $11 \mathrm{~L}$ & - & $11 \mathrm{~L}$ \\
\hline $2.0 \%$ & $26 \mathrm{H}$ & $26 \mathrm{H}$ & $14 \mathrm{I}$ & $21 \mathrm{I}$ & $12 \mathrm{I}$ & $19 \mathrm{I}$ \\
\hline $3.0 \%$ & $26 \mathrm{H}$ & $28 \mathrm{H}$ & $15 \mathrm{I}$ & $24 \mathrm{I}$ & $17 \mathrm{I}$ & $23 \mathrm{I}$ \\
\hline $\begin{array}{llll}\text { Epoxy with comp. III } \\
0.5 \%\end{array}$ & - & - & - & $13 \mathrm{I}$ & - & - \\
\hline $1.0 \%$ & - & - & - & $20 \mathrm{I}$ & - & - \\
\hline $2.0 \%$ & - & - & - & $26 \mathrm{H}$ & - & - \\
\hline $3.0 \%$ & - & - & - & $30 \mathrm{H}$ & - & - \\
\hline $\begin{array}{l}\text { Epoxy with comp. IV } \\
0.5 \%\end{array}$ & - & - & - & - & $17 \mathrm{I}$ & $9 \mathrm{~L}$ \\
\hline $1.0 \%$ & - & - & - & - & $20 \mathrm{I}$ & $13 \mathrm{I}$ \\
\hline $2.0 \%$ & - & - & $8 \mathrm{~L}$ & $7 \mathrm{~L}$ & $25 \mathrm{H}$ & $18 \mathrm{I}$ \\
\hline $3.0 \%$ & - & - & $8 \mathrm{~L}$ & $10 \mathrm{~L}$ & $28 \mathrm{H}$ & $22 \mathrm{I}$ \\
\hline Control \# & 35 & 35 & 36 & 38 & 35 & 37 \\
\hline
\end{tabular}

Where: - = No effect.

L: Low activity $=$ Mean of zone diameter $\leq 1 / 3$ of mean zone diameter of control.

I: Intermediate activity = Mean of zone diameter $\leq 2 / 3$ of mean zone diameter of control.

H: High activity $=$ Mean of zone diameter $>2 / 3$ of mean zone diameter of control.

\#: Chloramphencol in the case of Gram-positive bacteria, Cephalothinin the case of Gram-negative bacteria and cycloheximide in the case of fungi.

\section{Corrosion:-}

Since, 1,2,3-triazole compounds are heterocyclic compounds having three nitrogen atoms, when these moieties are adsorbed on the surface of the metal, each molecule covers large surface area and they can block the active sites by forming a co-ordinate covalent bond with the metal substrate, which leads to the decrease the rate of corrosion of the metal $^{(40)}$. And also, the polarity of the triazoles induces an electrostatic attraction on the metal surface so as to protect the metal substrate from corrosive medium.

The epoxy paint compositions were prepared by means of physically incorporating triazole derivatives by ratio of $0.5,1.0,2.0$ and $3.0 \%$ by weight into epoxy paint, were evaluated as the anti-corrosive. The paint formulations were evaluated on coated mild steel panels, the films thickness were adjusted about $50 \pm 5 \mu \mathrm{m}$. The coated steel panels were exposed to salt spray tests according to CSN ISO 9227 for $(500 \mathrm{~h})$.

Photographic reference standards were used to evaluate the degree of blistering, creepage and rusting. The reference standards highlight the various degrees of blistering that can potentially develop when paint systems are subjected to these specific test conditions. The blistering size is graded from 10 to 0 , where 10 represents of no blistering and 0 representative of the largest blister. Blistering frequency is denoted by [(few $(F)$, medium $(M)$, medium dense (MD) and dense (D)]. Coated specimens were subjected to a corrosive environment are also evaluated by recording the average (mean) maximum and minimum creepage from the scribe mark. Scribe failure is also rated on a scale from 10 to 0 , with 10 being zero $(\mathrm{mm})$ from the scribe mark and 0 is $16(\mathrm{~mm})$ from the scribe mark. Finally, visual 
comparison of the surface with photographic reference standards, to determine the percentage of the area that has been rusted., is carried out according to Painting Council (SSPC), The rust grade is rated on scale from 10 to 0 , where 10 is no rusting and 0 is suffering severe rusting.

The results of corrosion resistance of the painted films of prepared samples are given in (Table 3) and (Fig.3) explains the photo of the painted films after salt spray test $(3.5 \%$ of $\mathrm{NaCl})$. The results show that the compounds 4 amino-5- (trifluoromethyl)-4H-1,2,4-triazole-3-thiol (I) , 4-((4-chlorobenzylidene)amino)-5-(trifluoromethyl)-4H1,2,4-triazole-3-thiol (II) and 4-((furan-2- methylene)amino)-5-(trifluoromethyl)-4H-1,2,4-triazole-3-thiol (III) have an excellent anticorrosive properties due to of the presence triazole ring, all samples of compounds (II) and (III) approximately not affected during the probationary period due to the presence of the aromatic ring and imino group in addition to triazole ring, while complex (IV) has a poor anticorrosive properties.

Table 3:- Anticorrosive activities of modified epoxy varnish with new triazole derivatives (compounds I- IV).

\begin{tabular}{|c|rc|c|c|}
\hline Sample & \multicolumn{2}{|c|}{$\begin{array}{c}\text { Blistering } \\
\text { Frequency }\end{array}$} & Scribe failure (mm) & $\begin{array}{c}\text { Rust } \\
\text { grade }\end{array}$ \\
\hline Blank & 2 & $\mathrm{D}$ & 13 & 3 \\
\hline Epoxy with comp. I $0.5 \%$ & 5 & $\mathrm{M}$ & 7 & 5 \\
\hline $1.0 \%$ & 6 & $\mathrm{M}$ & 6 & 6 \\
\hline $2.0 \%$ & 8 & $\mathrm{~F}$ & 4 & 7 \\
\hline $3.0 \%$ & 8 & $\mathrm{~F}$ & 4 & 8 \\
\hline Epoxy with comp. II 0.5\% & 6 & $\mathrm{M}$ & 6 & 6 \\
\hline $1.0 \%$ & 8 & $\mathrm{M}$ & 5 & 7 \\
\hline $2.0 \%$ & 8 & $\mathrm{~F}$ & 4 & 8 \\
\hline $3.0 \%$ & 9 & $\mathrm{~F}$ & 4 & 8 \\
\hline Epoxy with comp. III 0.5\% & 8 & $\mathrm{~F}$ & 5 & 7 \\
\hline $1.0 \%$ & 8 & $\mathrm{~F}$ & 4 & 8 \\
\hline $2.0 \%$ & 9 & $\mathrm{~F}$ & 3 & 8 \\
\hline $3.0 \%$ & 9 & $\mathrm{~F}$ & 3 & 3 \\
\hline Epoxy with comp. IV 0.5\% & 3 & $\mathrm{D}$ & 11 & 3 \\
\hline $1.0 \%$ & 4 & $\mathrm{MD}$ & 10 & 4 \\
\hline $2.0 \%$ & 4 & $\mathrm{D}$ & 8 & 6 \\
\hline $3.0 \%$ & 5 & $\mathrm{M}$ & 7 & 8 \\
\hline
\end{tabular}




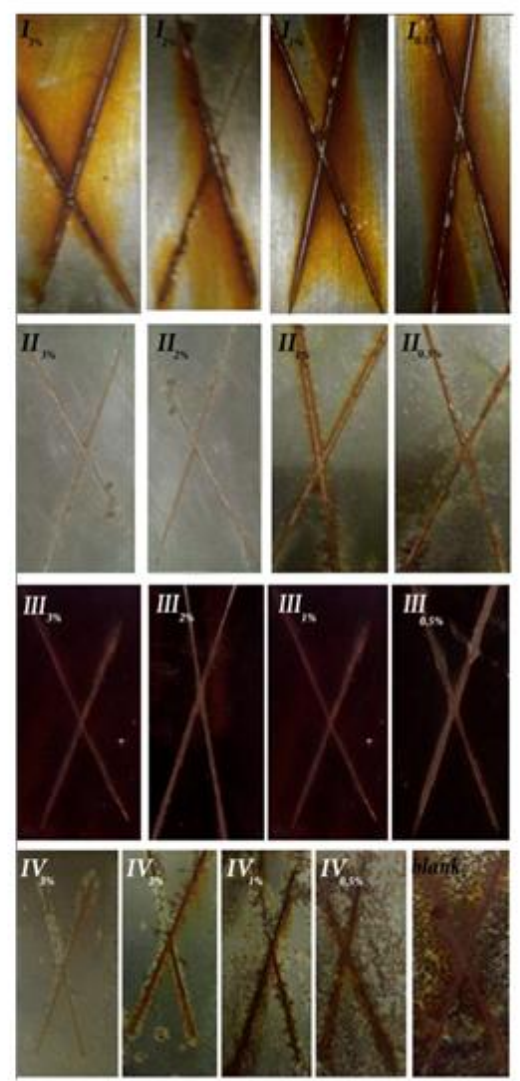

\section{Conclusion:-}

Figure 3:The photo of the painted steel after exposed to solid spray test

This study proved that the adding of triazole modifiers (I, I, III) improved physical properties of modified resins, but compound (IV) has some negative physical properties compared with that of coatings based on the widely used commercial epoxy resin. All modifier epoxy coatings posses antibacterial and antifungal activity by different ratio and also may be used as anticorrosive agents.

\section{References:-}

1. A.Maiorana, B.Subramaniam, R.Centore, X. Han, J. Robert,Linhardt, A. Gross, " Synthesis and Characterization of an Adipic Acid - Derived Epoxy Resin", J. POLYMER SCIENCE, 54 (2016) 2625-2631.

2. N. Abd El-Khalik, "Evaluation of Some Chromene Derivatives as Additives in Fire Retardant and Anticorrosive Coating Composition", The International J. Of Science \&Technoledge, 4 (2016) 140-147.

3. P.A. Sorensen, S.Kiil, K. Dam-Johansen, C.E. Weinell, " Anticorrosive coatings: a review", J. Coat. Technol. Res, 6 (2009) 135-176.

4. M. Nakazawa," Mechanism of Adhesion of Epoxy Resin to Steel Surface", J. Nippon Steel Technical Report, 63 (1994) 16-22..

5. M. M. Green, H. A. Wittcoff, Organic Chemistry Principles and Industrial Practice; Wiley-VCH: Weinheim; 2003.

6. J. L. Haynes, D. M. James," Antimicrobial surfaces and inhibition of microorganism growth thereby", US Pat.;4886505 (1989).

7. E. R. Kenawy, S. D. Worley, R. Broughton, "The chemistry and applications of antimicrobial polymers", J. Biomacromolecules, 8 ( 2007 ) 1359-1384 .

8. M. L. Knetsch and L. H. Koole,"New Strategies in the Development of Antimicrobial Coatings: The Example of Increasing Usage of Silver and Silver Nanoparticles"; J. Polymers, 3 (2011) 340-366.

9. I.Ledeţi,V.Bercean,A.Alexa,C.Şoica,L.M.Şuta, C.Dehelean, C.Trandafirescu, D.Muntean, M. Licker, A.Fuliaş, " Preparation and Antibacterial Properties of Substituted 1,2,4-Triazoles"; J. Chemistry, 2015 (2015) 1-5. 
10. Li. Y. Zhang, B. L. Wang, Y. Z. Zhan, Y. Zhang, X. Zhang, Z. M. Li;" Synthesis and biological activities of some fluorine- and piperazine-containing 1,2,4-triazole thione derivatives"; J. Chinese Chemical Letters, 27 (2016) 163-167.

11. S. H. Sumrra, Z. H. Chohan, "Metal based new triazoles: their synthesis, characterization and antibacterial/antifungal activities", J. Spectrochimica Acta Part A: Molecular and Biomolecular Spectroscopy, 98 (2012) 53-61.

12. P. Zoumpoulakis, C. Camoutsis, G. PairasM. Sokovic , J. Glamoclija, C. Potamitis, A. Pitsas , "Synthesis of novel sulfonamide-1,2,4-triazoles, 1,3,4-thiadiazoles and 1,3,4-oxadiazoles, as potential antibacterial and antifungal agents. Biological evaluation and conformational analysis studies"; J. Bioorganic and Medicinal Chemistry, 20 (2012) 1569-1583.

13. S. Maddila, R. Pagadala, S. B. Jonnalagadda, "1,2,4-Triazoles: a review of synthetic approaches and the biological activity"; J. Letters in Organic Chemistry, 10 (2013) 693-714.

14. J. Sharma, S. Ahmad, A. M. Shamsher, "Bioactive Triazoles: a potential review"; J. Chemical and Pharmaceutical Research, 4 (2012) 5157-5164.

15. M. M. Antonijevic, M. B. Petrovic, "Copper corrosion inhibitors. A review"; International J. Electrochemical Science, 3 (2008) $1-28$.

16. S.Kantheti, R. Narayan, K. V. S. N. Raju," Development of moisture cure polyurethane-urea coatings using 1,2,3-triazole core hyper branched polyesters"; J. Coat. Technol. Res, 10 (2013) 609-619.

17. F. Frgata, S. Renieri, A. Cristina, A. Elisabete,"Compatibility and Incompatibility in Anticorrosive Painting The Particular Case of Maintenance Painting); J. Prog. Org. Coat. 56 (2006) 257-268.

18. J. Shah, G.B. Bhagchandani, "Anti Corrosive Rubber Coating"; International J. of Engineering Sciences \&Research Technology, 2 (2013) 443-447.

19. J. Copal, P. Dwivedi, S. Sundaram,R.Prakash," inhibitive effect of chlorophytumborivilianum root extract on mild steel corrosion in $\mathrm{HCl}$ and H2SO4 solutions"; J. Ind. Eng. Chem. Res. 52 (2013) 10673-10681.

20. L.C.Kamal, Sethuraman, M.G.Opuntiol ,"An active principle of opuntiaelatior as an eco-friendlyinhibitor of corrosion of mild steel in acid medium"; J. Sustain. Chem. Eng. 2 (2014) 606-613.

21. K. Adardour, R. Touir, Y. Ramli, R. A. Belakhmima, M. EbnTouhami,C. KalonjiMubengayi, H. El Kafsaoui, E. M. Essassi , " Comparative inhibition study of mild steel corrosion in hydrochloric acid by new class synthesized quinoxaline derivatives: part I"; J. Res ChemIntermed 39 (2013) 1843-1855.

22. S. Tamilselvi, S. Rajeswari "The effect of triazoles and surfactants on the corrosion inhibition of carbon steel in acid solution"; J. Anti-Corrosion Methods and Materials, 50 (2003) 223-231.

23. Schmidt, G. "AApplications of inhibitors for acid media"; J. British Corrosion, 19 (1984) 165-176.

24. B. Mernari, L. El Kadi, S. Kertit, "2,5Bis (2-Thienyl)-1,3,4-oxadiazole as corrosion inhibitor of mild steel in acidic media"; J. Bull. Electrochem, 17 (2001) 115-122.

25. M.A. Quraishi, J.Rawat, M.Ajmal, "Dithiobiurets: a novel class of acid corrosion inhibitors for mild steel"; J. Appl. Electrochem, 30 (2000) 745-751.

26. EL. M. Achouri, S. Kertit, M. Salem, E. M.Essassi, M. Jellal, "3-mercapto 1,2,4-triazole derivatives as corrosion inhibitors for iron in hydrochloric acid solution"; J. Bull. Electrochem. 14 (1998) 462-468.

27. F. Bentiss, M. Traisnel, M.Lagrenee; "Inhibition of acidic corrosion of mild steel by 3,5-diphenyl-4H-1,2,4triazole,”; J. Applied Surface Science, 161 (2000) 194-202.

28. K. G. Gamal; "Effect of copper cation on corrosion of steel by tolytriazole in acid medium"; J. Chem. Technol., 7 (2000) 300-306.

29. M. A. Quraishi, M. Q. Ansari, S. Ahmad, G. Venkatachari; "Influence of some multifunctional triazoles on corrosion of mild steel in boiling hydrochloric acid solutions"; J.Bull. Electrochem., 14 (1998) 302-305.

30. M. Chen , X. F. Wang, S.Wang,Y. X.Feng, F. Chen ,C. L. Yang; " Synthesis, characterization and fungicidal activities of novel fluorinated 3,5-disubstituted-4H-1,2,4-triazol-4-amines"; J. Fluorine Chemistry 135 (2012) 323-329.

31. N.G. Heatley; "A method for the assay of penicillin"; J. Biochem; 38 (1944) 61-65.

32. A.K. Singh, O.P. Pandey, S.K. Sengupta ; "Synthesis, spectral characterization and biological activity of zinc(II) complexes with 3-substituted phenyl-4-amino-5-hydrazino-1, 2, 4-triazole Schiff bases"; J.

Spectrochimica Acta, 85 (2012) 1-6. 
33. P. Tyagi, S. Chandra, B.S. Saraswat, D. Yadav,; "Design, spectral characterization, thermal, DFT studies and anticancer cell line activities of $\mathrm{Co}(\mathrm{II}), \mathrm{Ni}(\mathrm{II})$ and $\mathrm{Cu}(\mathrm{II})$ complexes of Schiff bases derived from 4-amino-5(pyridin-4-yl)-4H-1,2,4-triazole-3-thiol"; J. Spectrochimica Acta, 145 (2015) 155-164.

34. S. Rakshit,D. Palit, S. K.S. Hazari, S. Rabi, T. G. Roy, F. Olbrich, D. Rehder, "Synthesis, characterization and biomedical activities of molybdenum complexes of tridentate Schiff base ligands. Crystal and molecular structure of $\left[\mathrm{MoO}_{2}\left(\mathrm{~L}^{10}\right)(\mathrm{DMSO})\right]$ and $\left[\mathrm{MoO}_{2}\left(\mathrm{~L}^{11}\right)(\mathrm{DMSO}) " ;\right.$ J. Polyhedron 117 (2016) 224-230.

35. Z. Asadi, M. Asadi, M. R. Shorkaei, " Synthesis, characterization and DFT study of new water-soluble aluminum(III), gallium(III) and indium(III) Schiff base complexes: effect of metal on the binding propensity with bovine serum albumin in water"; J. Iran. Chem. Soc. 13 (2016) 429-442.

36. M. Jazestani, H, Chiniforoshan, L, Tabrizi, P. McArdle, B. Notash, "Synthesis, crystal structure of nickel (II) complexes of 4-nitro phenylcyanamide: Comparative in vitro evaluations of biological perspectives"; J. Inorganic Chim. Acta, 450 (2016) 402-410.

37. N. Mathew, M. Sithambaresan, M. R. P. Kurup, " Spectral studies of copper (II) complexes of tridentate acylhydrazone ligands with heterocyclic compounds as coligands: X-ray crystal structure of one acylhydrazone copper (II) complex"; J. Spectrochim. Acta, 79 (2011) 1154- 1161.

38. Haythem, Saadeh, Ibrahim M. Mosleh, Amal G. Al-Bakri, Mohammad S. Mubarak " Synthesis and antimicrobial activity of new 1,2,4-triazole-3-thiol metronidazole derivatives"; J. Monatshefte für Chemie, 141 (2010) 471-478.

39. Nurhan G“UMR"UKC, "UO־GLU, Mevlut SERDAR, Elif C , EL`IK, Ali SEV`IM, Neslihan DEM`IRBAS " Synthesis and Antimicrobial Activities of Some New 1,2,4-Triazole Derivatives "; J. Turk . Chem., 31 (2007) $335-348$.

40. K. Sasidhar,N. Ramanuj, K. V. S. N. Raju," The impact of 1,2,3-triazoles in the design of functional coatings"; J. RSC Adv. 5 (2015) 3687-3708. 